\title{
EMBRYONIC MORTALITY DURING THE PRE- AND POST-IMPLANTATION PERIODS OF PREGNANCY IN MATURE MICE AFTER SUPEROVULATION
}

\author{
HEATHER M. BEAUMONT AND AGNES F. SMITH* \\ Department of Anatomy, Medical School, University of Birmingham, Birmingham 15
}

(Received 27th Fanuary 1975)

\begin{abstract}
Summary. Sexually mature mice were stimulated to superovulate by giving exogenous gonadotrophins at known stages of the oestrous cycle. Untreated animals which ovulated spontaneously served as controls. The number of oocytes ovulated by each female was estimated from counts of the number of CL of pregnancy, and the incidence of embryonic mortality during the pre- and post-implantation stages of pregnancy was assessed from the number of zygotes recovered from the reproductive tract at 2.0 and 4.0 days post coitum and of conceptuses examined at 7.5 and 11.5 days post coitum.

The mean number of oocytes ovulated by treated animals was 39.54 , compared with 12.80 in controls: in mice which had superovulated, $44 \%$ of the ova were lost before implantation compared with about $10 \%$ in the controls. Further losses occurred about the time of implantation and at mid-pregnancy and thus the number of embryos classified as normal rarely exceeded the maximum found in controls. Death at midpregnancy seemed to be preceded by developmental retardation.

The possibility that genetic and environmental factors play a role in embryonic loss after superovulation is discussed.
\end{abstract}

\section{INTRODUCTION}

Techniques for inducing superovulation in mice by the administration of exogenous gonadotrophins are well established. Under optimal conditions, 80 or more ova can be obtained from prepubertal animals (Gates, 1971) and 30 to 40 from mature mice (Fowler \& Edwards, 1957; Biggers et al., 1971). There are two possible reasons why mature animals yield fewer ova; (i) the number of large follicles capable of responding to gonadotrophic hormone is lower than that found in the ovaries of immature mice (Jones \& Krohn, 1961), and (ii) investigators have generally failed to synchronize the time of administration of exogenous gonadotrophins with endogenous changes of the normal oestrous cycle (McLaren \& Michie, 1959; Edwards et al., 1963).

The results of previous studies have consistently shown that pre- and postnatal mortality are higher in immature and mature mice which have super-

* Present address: Department of Pathology, St Paul's Hospital, 24 Endell Street, London WG2H 9AE. 
ovulated than in mature controls which ovulated spontaneously. Death most commonly occurs during cleavage (Allen \& McLaren, 1971), about the time of implantation, at mid-pregnancy and at or shortly after parturition (Edwards \& Fowler, 1959; McLaren \& Michie, 1959). The factors responsible for embryonic loss have not been defined. Two possibilities have to be considered; first, that treatment with exogenous gonadotrophins increases the proportion of abnormal ova which are shed, and second, that fertilization and development of the zygote are adversely affected by conditions in the maternal environment.

Gates $(1956,1965,1971)$ believes that the ova produced by mice which have superovulated are gentically normal and capable of normal development. $\mathrm{He}$ reported that there was no difference between zygotes produced by immature mice which superovulated and mature controls which ovulated spontaneously with respect to the proportion which (a) developed in vitro from the 2-cell to the blastocyst stage and (b) gave rise to viable embryos when transferred, as blastocysts, to the uteri of suitable recipients. It is possible, however, that the zygotes used in these experiments were derived from a population which had already been subject to selection. Information on the number of oocytes ovulated by each animal was not available: hence any losses which occurred between the time of ovulation and recovery were not taken into account.

A number of authors have ascribed embryonic loss after superovulation to environmental factors; e.g. competition between embryos (Edwards \& Fowler, 1959; Edwards et al., 1963; McLaren \& Michie, 1959; Allen \& McLaren, 1971) or maternal systemic factors such as nutritional stress or insufficiency of progesterone (McLaren \& Michie, 1956, 1959).

The present study was undertaken to examine the hypothesis that embryonic loss in mice which have superovulated is due to factors in the maternal environment and not to genetic deficiencies in the oocytes themselves. Sexually mature mice were used to ensure that the treated and control animals were comparable, and to avoid the possibility of pregnancy failure due to the immaturity of the mother. The treatment regimen was designed so that exogenous hormones were given at known stages of the oestrous cycle. In order to extend previous investigations, a quantitative study of embryonic loss during the pre- and postimplantation stages of pregnancy was carried out: the stages at which death occurred were defined and the incidence of mortality calculated, for each animal, in relation to the number of oocytes ovulated.

\section{MATERIALS AND METHODS}

\section{Animals and treatment regimen}

Forty-three virgin female mice of the LACA strain, aged 6 to 8 weeks, were used. All the animals were housed in a room in which the lighting was controlled to give $14 \mathrm{hr}$ light $/ 10 \mathrm{hr}$ dark per day (dark period 14.00 to 24.00 hours, see Text-fig. 1). Food and water were freely available.

The technique for administering exogenous gonadotrophins was adapted from those previously shown to induce superovulation in mature mice (Fowler \& Edwards, 1957; Edwards \& Fowler, 1959; Edwards \& Gates, 1959; Edwards et al., 1963). Vaginal smears were taken daily until at least two 
normal oestrous cycles had been recorded. Between 10.00 and 11.00 hours on the first day of dioestrus (Text-fig. 1) experimental animals were given an intraperitoneal injection of 3 i.u. PMSG (Gestyl:Organon Laboratories L.td); $47 \mathrm{hr}$ later they received 3 i.u. HGG (Pregnyl: Organon). The HGG was given at the expected time of the $\mathrm{LH}$ 'surge', estimated to occur 15 to $20 \mathrm{hr}$ after the mid-point of the second period of darkness following administration of PMSG (Gates, 1971; Text-fig. 1). Treated females were individually caged overnight with young males of proven fertility and were examined for copulation plugs about 9 to $11 \mathrm{hr}$ after the estimated time of mating. Control animals were housed with males and examined for copulation plugs. The day a copulation plug was found was designated Day 0.5 of pregnancy $(0.5$ days post coitum, p.c.).

Experimental and control animals were killed at $2 \cdot 0,4 \cdot 0,7 \cdot 5$ and 11.5 days p.c.: the number of animals in each group is shown in Table 2.
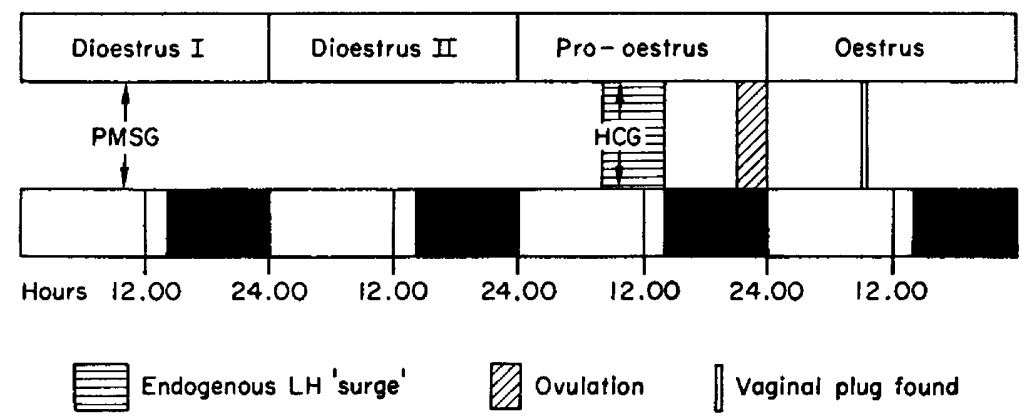

TEXT-FIG. 1. Times of administration of exogenous gonadotrophins shown in relation to the 24-hr lighting schedule and the stages of the oestrous cycle.

\section{Preimplantation stages of pregnancy: recovery of zygotes from the reproductive tract}

On the 2nd day of pregnancy (about $42 \mathrm{hr}$ p.c.), treated and control animals were killed by means of ether vapour and the reproductive tract removed. The ovaries were freed from surrounding tissues and placed in Bouin's aqueous fixative for subsequent histological processing. Each oviduct was separated from the uterine horn at the uterotubal junction and then flushed with normal saline, using a blunted 30-gauge needle fitted to a $1 \mathrm{ml}$ syringe. Material flushed from the tube was examined under a dissecting microscope $(\times 120$ and $\times 250)$. Normal and abnormal zygotes were counted and those which appeared normal were classified according to their stage of development. Uncleaved 'ova' were classified as abnormal; the technique used in this study did not show whether they had been fertilized.

Zygotes were also recovered on Day 4.0 (about $89 \mathrm{hr}$ p.c.). The ovaries and oviducts were placed in fixative and the paired uterine horns were separated at the cervix and flushed individually. Zygotes were examined and classified as described.

Preparation and examination of ovaries and uterine contents

Ovaries. After fixation the ovaries were dehydrated and embedded in paraffin 
wax. Serial sections, $7 \mu \mathrm{m}$ thick, were cut and stained with Weigert's iron haematoxylin and counterstained with eosin. Sections were scanned in sequence using a Zeiss binocular microscope $(\times 320)$ and corpora lutea of pregnancy (CLP) and corpora lutea accessoria (CLA, see below) were counted.

Uterine contents. In mice autopsied at 7.5 days, the reproductive tract was exposed and the number of swellings in each uterine horn was recorded. The ovaries and entire reproductive tract were retained for subsequent histological examination. To prevent shrinkage, each uterine horn was pinned onto a card before being placed in Bouin's aqueous fluid: subsequent histological procedures were the same as those described above. Serial sections were examined under the light microscope $(\times 80$ and $\times 320)$ and the number of implantation sites was recorded. Conceptuses were classified as follows. (i) Normal. The conceptus had attained a degree of development commensurate with its known gestational age (Snell \& Stevens, 1966; Theiler, 1972). (ii) Retarded. The conceptus was normal in appearance but had not reached the stage of development characteristic of its gestational age; conceptuses were assigned to this group only if the delay was estimated to be $24 \mathrm{hr}$ or more, since there is considerable variation, both within and between litters, in the rate of development (Theiler, 1972). (iii) Degenerating. The conceptus showed abnormalities judged to be incompatible with further development; embryonic tissues were disorganized and placental and decidual tissues showed changes indicative of regression and resorption.

In addition to the qualitative assessment of conceptuses, the number of sections occupied by the embryonic cylinder was counted and its diameter calculated.

In mice autopsied at 11.5 days, the uterine contents were examined in situ. A cut was made along the antimesometrial side of the uterine wall and the embryos were 'shelled out' while remaining attached to their respective placentae and usually within an intact amnion. A mounted magnifying glass was used to examine the form and size of the embryonic body and to observe the pulsations of the heart. The conceptuses were classified as follows. (i) Normal and viable; (ii) degenerating: embryonic and placental tissues identifiable but disorganized, suggesting recent death; (iii) resorption site or 'mole': apparently amorphous mass of embryonic and decidual tissues, indicating that death occurred shortly after implantation.

\section{Quantitative analysis}

The number of oocytes ovulated by each animal was estimated from counts of the number of CLP; the GLA, follicles which failed to ovulate and contained a 'trapped' oocyte, were recorded separately. Since the number of CL in each animal was independent of the stage of pregnancy at autopsy, data have been pooled for the calculation of mean values for treated animals and controls (Table 1).

Mean values for (a) the total number of zygotes or embryos and (b) the number of normal zygotes or embryos were calculated for mice which superovulated and for controls, autopsied at the different stages of pregnancy (Table 2). The percentage of normal zygotes or embryos and the numbers 
which were retarded or degenerating were then calculated for each group in relation to the total number of zygotes or embryos found (Table 3 ). The total number of zygotes recovered, or of implantation sites found, was also expressed as a percentage of the mean number of oocytes ovulated by mice in the respective group (Table 3 ).

Inspection of the results suggested that statistical analysis would be inappropriate in view of the variability of the data obtained from mice which had superovulated.

Five of the animals which received exogenous hormone were excluded from the analysis: one failed to respond to the treatment and four, which had superovulated, were without normal zygotes or implantation sites, and hence it was impossible to determine the stage(s) at which embryonic death occurred.

\section{RESULTS}

\section{Numbers of corpora lutea and ovulations}

The present findings clearly demonstrate that the treatment regimen used in this study was successful in stimulating superovulation in mature mice: the mean number of oocytes ovulated by treated animals was 39.54, compared with $12 \cdot 80$ in controls (Table 1). Experimental animals showed considerable variability, however, with respect to the number of oocytes shed and CLA occurred with greater frequency and in higher numbers than in controls (Table $1)$ : the treated animal which had the smallest number of ovulations (17, i.e. within the range for controls) also had the greatest number of CLA.

Table 1. The numbers of corpora lutea of pregnancy and corpora lutea accessoria in mice induced to superovulate and untreated controls

\begin{tabular}{lcc}
\hline & Control mice & $\begin{array}{c}\text { Superovulating } \\
\text { mice }\end{array}$ \\
\hline No. of animals & 15 & 22 \\
Total no. of corpora lutea & $12.93(10 \cdot 0-17 \cdot 0)$ & $44 \cdot 18(23 \cdot 0-72 \cdot 0)$ \\
No. of corpora lutea of pregnancy & $12.80(10 \cdot 0-17 \cdot 0)$ & $39 \cdot 54(17 \cdot 0-72 \cdot 0)$ \\
No. of corpora lutea accessoria & $0 \cdot 13^{*}$ & $4.64(0-26 \cdot 0) \dagger$ \\
\hline
\end{tabular}

Values are means with the range in parentheses.

* Two mice each had one CLA.

$\dagger$ Sixteen mice had CLA.

\section{Embryonic development and mortality}

Preimplantation period. The number of zygotes recovered at 2.0 days p.c. represented about $90 \%$ and $100 \%$ of the oocytes ovulated by treated and control animals, respectively, showing that losses up to this stage are small (Table 3 ). Almost all of the zygotes recovered from mice which ovulated spontaneously were classified as normal (Tables 2 and 3). Of these, the majority $(52 \%$ ) had completed the first cleavage division and were at the 2-cell stage, $35 \%$ 
Table 2. The number and condition of zygotes or embryos recovered from mice induced to superovulate and untreated controls at different stages of pregnancy

\begin{tabular}{|c|c|c|}
\hline & Control mice & $\begin{array}{c}\text { Superovulating } \\
\text { mice }\end{array}$ \\
\hline $\begin{array}{l}\text { Day } 2 \cdot 0 \\
\text { No. of animals } \\
\text { No. of zygotes } \\
\text { No. of normal zygotes }\end{array}$ & $\begin{array}{l}4 \\
13 \cdot 75(12 \cdot 0-17 \cdot 0) \\
12 \cdot 0(11 \cdot 0-13 \cdot 0)\end{array}$ & $\begin{array}{c}5 \\
28 \cdot 6(14 \cdot 0-40 \cdot 0) \\
19 \cdot 0(7 \cdot 0-37 \cdot 0)\end{array}$ \\
\hline $\begin{array}{l}\text { Day } 4.0 \\
\text { No. of animals } \\
\text { No. of zygotes } \\
\text { No. of normal zygotes }\end{array}$ & $\begin{array}{c}4 \\
11 \cdot 0(9 \cdot 0-13 \cdot 0) \\
10 \cdot 5(8 \cdot 0-12 \cdot 0)\end{array}$ & $\begin{array}{c}6 \\
16 \cdot 67(4 \cdot 0-28 \cdot 0) \\
14 \cdot 0 \quad(3 \cdot 0-25 \cdot 0)\end{array}$ \\
\hline $\begin{array}{l}\text { Day } 7.5 \\
\text { No. of animals } \\
\text { No. of embryos } \\
\text { No. of normal embryos }\end{array}$ & $\begin{array}{c}4 \\
12.5(10 \cdot 0-16.0) \\
12.5(10 \cdot 0-16 \cdot 0)\end{array}$ & $\begin{array}{c}6 \\
18 \cdot 2(7 \cdot 0-29 \cdot 0) \\
12 \cdot 0(5 \cdot 0-19 \cdot 0)\end{array}$ \\
\hline $\begin{array}{l}\text { Day } 11.5 \\
\text { No. of animals } \\
\text { No. of embryos } \\
\text { No. of normal embryos }\end{array}$ & $\begin{array}{c}4 \\
9 \cdot 75(9 \cdot 0-11 \cdot 0) \\
8 \cdot 75(7 \cdot 0-10 \cdot 0)\end{array}$ & $\begin{array}{c}5 \\
26 \cdot 0(21 \cdot 0-30 \cdot 0) \\
15 \cdot 40(7 \cdot 0-24 \cdot 0)\end{array}$ \\
\hline
\end{tabular}

Values are means with the range in parentheses.

Table 3. Percentage recovery* and percentage $\dagger$ of normal zygotes or embryos and of embryos at different stages of degeneration (see text) in mice induced to superovulate and untreated controls

\begin{tabular}{|c|c|c|}
\hline & $\begin{array}{c}\text { Control } \\
\text { mice }\end{array}$ & $\begin{array}{c}\text { Superovulating } \\
\text { mice }\end{array}$ \\
\hline $\begin{array}{l}\text { Day } 2 \cdot 0 \\
\text { Recovery } \\
\text { Normal zygotes }\end{array}$ & $\begin{array}{r}100 \cdot 00 \\
87 \cdot 27\end{array}$ & $\begin{array}{l}91 \cdot 08 \\
66 \cdot 43\end{array}$ \\
\hline $\begin{array}{l}\text { Day } 4 \cdot 0 \\
\text { Recovery } \\
\text { Normal zygotes }\end{array}$ & $\begin{array}{l}88 \cdot 0 \\
95 \cdot 45\end{array}$ & $\begin{array}{l}56 \cdot 18 \\
83 \cdot 98\end{array}$ \\
\hline $\begin{array}{l}\text { Day } 7 \cdot 5 \\
\text { Recovery } \\
\text { Normal zygotes } \\
\text { Retarded } \\
\text { Degenerating }\end{array}$ & $\begin{array}{c}89 \cdot 20 \\
100 \cdot 0 \\
- \\
-\end{array}$ & $\begin{array}{l}41 \cdot 55 \\
65 \cdot 93 \\
15 \cdot 55 \\
18 \cdot 29\end{array}$ \\
\hline $\begin{array}{l}\text { Day } 11.5 \\
\text { Recovery } \\
\text { Normal zygotes } \\
\text { Mid-pregnancy death } \\
\text { 'Moles' }\end{array}$ & $\begin{array}{r}93 \cdot 39 \\
89 \cdot 74 \\
7 \cdot 69 \\
2 \cdot 56\end{array}$ & $\begin{array}{l}47 \cdot 79 \\
59 \cdot 23 \\
27 \cdot 69 \\
13 \cdot 07\end{array}$ \\
\hline \multicolumn{3}{|c|}{ * Total no. zygotes/embryos found $\%$} \\
\hline
\end{tabular}


had undergone further division, and $13 \%$ were abnormal. The zygotes recovered from mice which superovulated were more advanced in their development. Only $3 \%$ were 2 -celled, the majority $(62 \%)$ had reached the 3 - or 4 -cell stage or had developed further. About one-third of the 'ova' recovered from treated animals were degenerating (Table 3 ). Included in this category were uncleaved 'ova', empty zonae and zygotes which had undergone cleavage but had apparently abnormal blastomeres.

Most of the abnormal 'ova' seemed to have been eliminated by 4.0 days p.c. when the recovery rate of the oocytes ovulated by treated animals had fallen to $56 \%$, compared with about $90 \%$ in controls (Table 3 ). Most of the zygotes recovered at 4.0 days, from both treated animals and controls, were classified as normal (Tables 2 and 3 ) and had become blastocysts.

Post-implantation period. The results of the quantitative analysis indicate that almost all of the zygotes which survive to 4.0 days p.c. and form blastocysts subsequently undergo implantation, the recovery rate at 7.5 and 11.5 days p.c. remaining at 40 to $50 \%$ in mice which superovulated and at about $90 \%$ in controls (Table 3). Although there was an increase in the total number of implantation sites in mice which received exogenous gonadotrophins, 13 to $18 \%$ of the embryos degenerated at, or shortly after, implantation (compared with $<3 \%$ in controls) and further losses occurred at mid-pregnancy (Table 3, see below). Thus the number of normal conceptuses rarely exceeded the upper end of the range in controls (Table 2).

All conceptuses were examined microscopically at 7.5 days and all 50 of those found in mice which ovulated spontaneously were normal (Tables 2 and 3; Pl. 1, Fig. 1). Of the 109 sites in mice which superovulated, twenty $(18 \%$, see Table 3) were degenerating. Half of these sites contained an atrophic blastocyst in a uterine crypt (Pl. 1, Fig. 2) and half comprised a few trophoblastic giant cells associated with decidual tissue; derivatives of the inner cell mass were rarely seen (Pl. 1, Fig. 3).

In five of the six mice which superovulated $(29,21,20,16$ and 7 implantation sites), all of the conceptuses which were morphologically normal were less advanced in their development than controls of the same gestational age. According to Theiler's (1972) descriptions, most showed a delay of between 12 and $24 \mathrm{hr}$ and hence came within the range classified as 'normal' in this study (Pl. 1, Fig. 4). Seventeen embryos (about 16\%, see Table 3) which showed a delay of $>24 \mathrm{hr}$ were classified as retarded (Pl. 1, Fig. 5). Four of the six animals examined at 7.5 days after superovulation had one implantation site which contained two embryos with separate chorionic vesicles: most of these embryos were also classified as retarded. Developmental retardation was not observed in the litters of untreated mice.

These qualitative observations were confirmed by measurements of the embryonic cylinder. The mean diameter was $470 \mu \mathrm{m}$ in controls and $172 \mu \mathrm{m}$ in the five treated animals whose embryos showed retardation. In the one treated animal in which development of the sixteen conceptuses was judged to be normal, the mean diameter of the embryonic cylinder was $500 \mu \mathrm{m}$.

Two types of degenerating conceptuses were found in mice autopsied at 11.5 days p.c. Resorption sites or 'moles' (about $13 \%$ of conceptuses) probably 
represented losses which occurred during the peri-implantation period, while an additional $28 \%$ of embryos apparently degenerated some time after the initiation of organogenesis (Table 3). Macroscopic examination of these sites revealed remnants of organized placental tissue and an embryo which was characteristically underdeveloped, small and ischaemic, or was undergoing autolysis.

\section{Sources of error}

Counts of the number of CLP provide an accurate method for assessing the number of oocytes ovulated. Some difficulty was experienced in counting the number of CL when the number present in any one ovary was high (30 to 40). However, the results of replicate estimations suggested that any errors would be small.

The procedure used to recover zygotes, by flushing them from the reproductive tract, may be another source of error. The fact that 90 to $100 \%$ of the oocytes ovulated were subsequently recovered from the oviducts at 2.0 days p.c. suggests that very few losses occurred.

It is possible that, of the embryos examined at mid-pregnancy, some at an early stage of degeneration were wrongly classified as 'normal and viable'. When the number of implantation sites was large, it was not always feasible to examine all of the embryos before the circulatory system had ceased to function: classification was then based on external appearance only.

\section{DISCUSSION}

The results of the present study confirm and extend those of previous authors who have investigated embryonic development and mortality after superovulation in the mouse. At all stages of pregnancy examined, the mean number of zygotes or embryos found in mice which superovulated was higher than in controls but a smaller proportion was classified as normal. Almost half the oocytes produced by treated animals were lost before implantation, whereas only about $10 \%$ of those ovulated spontaneously failed to implant. The incidence of embryonic death at or shortly after implantation and at mid-pregnancy also

\section{EXPLANATION OF PLATE I}

Implantation sites in mice autopsied at 7.5 days p.c. Fig. 1 shows a conceptus recovered from a mouse which ovulated spontaneously; the remaining sites are from mice which had superovulated. All sections were cut in a transverse plane at right angles to the long axis of the uterus: the mesometrial border lies towards the upper margin of the Plate. $\times 65$.

FIG. 1. Normal conceptus ( $e=$ ectoplacental cone; $n p=$ neural plate; $d=$ decidual tissue).

FIG. 2. Atrophic blastocyst (arrowed).

Fig. 3. Cellular debris (cd) in implantation chamber.

FIG. 4. Conceptus classified as normal but showing developmental retardation of approximately $12 \mathrm{hr}$.

Fig. 5. Conceptus classified as retarded and showing developmental retardation of approximately $24 \mathrm{hr}$. 
PLATE
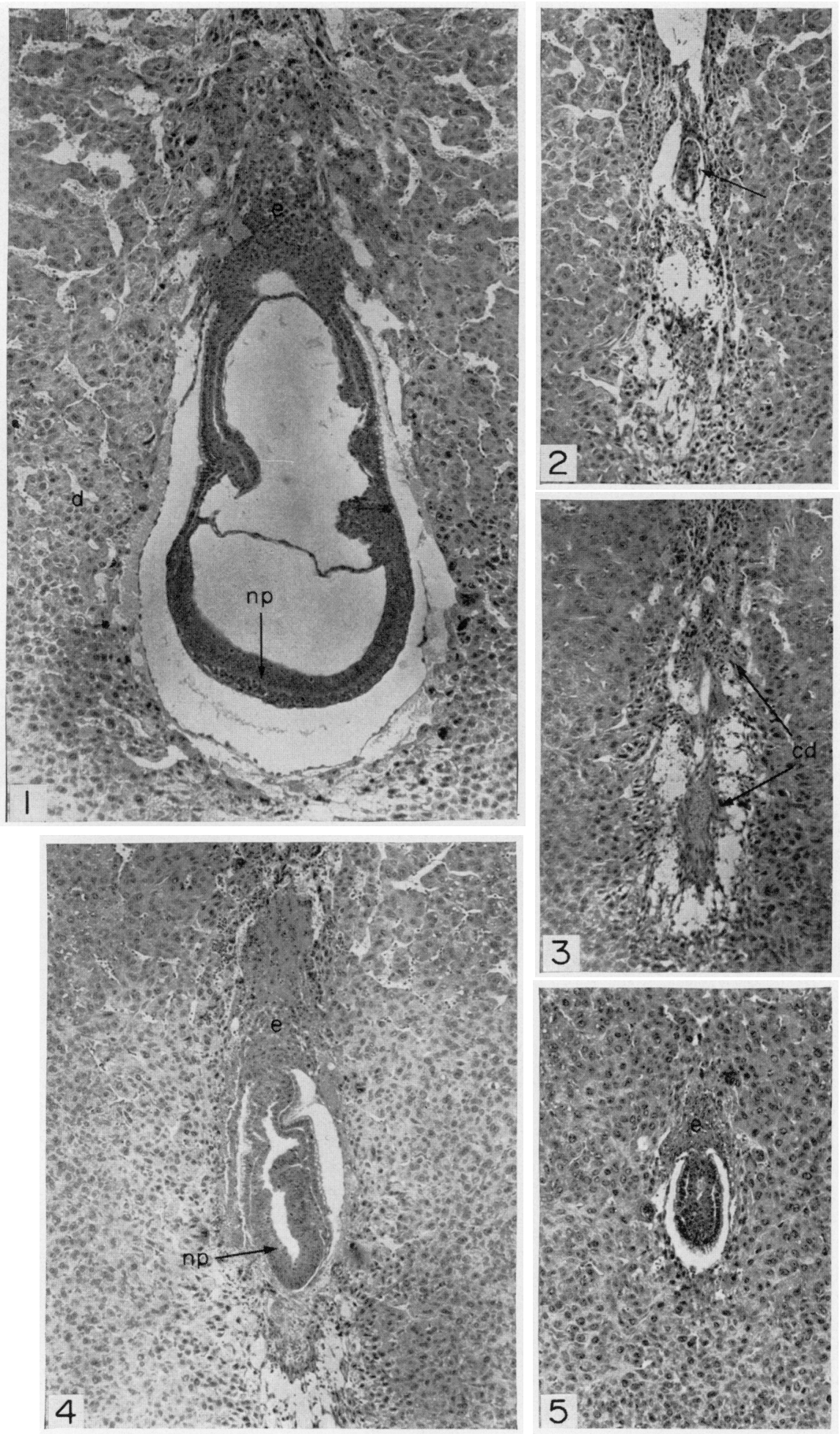

(Facing p. 444) 
increased after superovulation and it appears that death at mid-pregnancy may be preceded by developmental retardation.

The treatment regimen, designed to ensure that HCG was administered at the expected time of the LH 'surge', was slightly more successful than those used by previous authors with respect to the number of oocytes ovulated. More than half the mice included in the present study produced 40 oocytes or more, although there was wide variation in the number shed by different animals (range 17 to 72 versus 3 to 38 of Fowler \& Edwards, 1957). In addition, CLA occurred with greater frequency and in higher numbers in treated animals than in controls (see also Edwards et al., 1963). Retention of the oocyte may be indicative of a lack of synchrony between the time of rupture of the follicle and the onset of luteinization which, in turn, may reflect differences in the timing of the response to exogenous and endogenous hormones or variations in the sensitivity of growing follicles. McLaren (1967) found that variation in the number of ovulations was markedly reduced if a dose of 2 i.u. PMSG was divided into six portions and given over $24 \mathrm{hr}$. Gates (1971) considers that optimal results are obtained in immature animals only if HCG is administered at least $3 \mathrm{hr}$ in advance of the expected LH 'surge'.

Our findings have demonstrated that the number of 'ova' recovered at 2.0 days provides a reasonable indication of the number ovulated, very few $(<10 \%)$ being lost before this time. The results of the quantitative analysis of loss between 2.0 and 4.0 days correspond closely with those of Allen \& McLaren (1971), despite differences with respect to the strain of mouse and the treatment regimen. The loss of ova or zygotes during the preimplantation period may be due to abnormalities or failure of the process of fertilization, genetic deficiencies in the oocyte, or to an unfavourable environment.

The developmental capacity of oocytes is known to be reduced if the process of ovulation is prolonged or if insemination is delayed (Austin, 1970). Edwards $\&$ Gates (1959), however, reported that the timing of ovulation and fertilization was unchanged in mice subjected to treatment similar to that used in the present study.

Further information is required to confirm or deny the assertion of Gates $(1956,1965,1971)$ that the oocytes produced by mice which have superovulated are genetically normal. Fujimoto et al. (1974) have recently reported that $10 \%$ of the blastocysts recovered from rabbits which had superovulated had chromosomal abnormalities. It is not known whether the considerable losses recorded in the present study during the preimplantation period were due to genetic abnormalities in the oocytes or to failure of fertilization.

Development during the preimplantation period may be adversely affected by factors in the maternal environment. Steroid hormones are known to influence the rate of cleavage and the proportion of ova which form blastocysts both in vivo (Witenberger-Torres, 1964, cited by McLaren \& Bowman, 1973) and in vitro (Whitten, 1957; Daniel, 1964; Kirkpatrick, 1971). Our observation that almost all of the zygotes recovered at $2 \cdot 0$ days from mice which superovulated were more advanced in their development than those from controls is consistent with the observations of Allen \& McLaren (1971). These authors found that there was no change in the rate of cleavage but reported 
that ova from treated mice began dividing about $5 \mathrm{hr}$ earlier than those from controls, leading to a large difference in cell number by 4.0 days. Changes in the maternal hormonal environment may also be responsible for an increased rate of tubal transport, previously described in immature mice which had been induced to superovulate (Gates, 1971). Zygotes have also been found in the uteri of adult mice $24 \mathrm{hr}$ earlier than expected after treatment with exogenous gonadotrophins; many of the zygotes showed abnormal features (H. M. Beaumont and A. F. Smith, unpublished observation). Gates (1971) suggests that zygotes arriving prematurely in the uterus are unable to adapt to their environment and so degenerate. Harrington (1965) considers that accelerated tubal transport is indicative of excessive oestrogen and insufficient progesterone (see also Greenwald, 1967).

The results of our quantitative analysis indicate that, although some further losses occur after 4.0 days, most of the zygotes which survive to the blastocyst stage subsequently undergo implantation. Thus, even if there are changes in the hormonal environment which affect development during the pre-implantation period, the hormonal requirements for implantation seem to be fulfilled (Psychoyos, 1967). The total number of implantation sites found at 7.5 days was higher in treated mice than in controls (18.2 and 12.5 respectively, compared with 19.0 and 9.5 of McLaren \& Michie, 1959), but microscopical examination showed that about $18 \%$ of the sites were occupied by degenerating embryos. Primary trophoblastic giant cells could be identified in most instances (Dickson, 1966; Snell \& Stevens, 1966) and these were probably responsible for inducing a decidual reaction (Gardner, 1971, 1972). Embryos which degenerate after inducing a decidual reaction appear as 'moles' at later stages of pregnancy $(13 \%$ in treated animals and $3 \%$ in controls, compared with 16 to $32 \%$ and $3 \%$; Fowler \& Edwards, 1957; McLaren \& Michie, 1959).

In the majority of the experimental animals examined at 7.5 days p.c., all of the conceptuses which showed differentiation of the trophoblast and inner cell mass were, nevertheless, retarded with respect to growth and morphogenesis. The results of the quantitative study suggest that the majority of these embryos survive to mid-pregnancy. It may therefore be inferred that retardation of approximately $12 \mathrm{hr}$ does not preclude further development, while a delay of about $24 \mathrm{hr}(16 \%$ of sites at 7.5 days $)$ or slightly less may be a prelude to death during early organogenesis (28\% of sites at 11.5 days). A similar pattern of growth retardation has been reported amongst the conceptuses of rats treated with trypan blue (Berry, 1970), a dye which is thought to interfere with the nutritive function of the yolk sac (Beck \& Lloyd, 1966). The developmental retardation which occurs after superovulation may also be due to a nutritional insufficiency which may, in turn, be secondary to an hormonal imbalance or deficiency, affecting the differentiation and functional activity of the decidua or other uterine tissues.

It has previously been reported that the proportion of embryos dying at midpregnancy is directly related to the number of implantation sites: Fowler \& Edwards (1957) and McLaren \& Michie (1959) showed that losses rose to between 10 and $30 \%$ of sites when the number of conceptuses per uterine horn exceeded seven or eight. Inspection of our data revealed a similar trend. 
Thus the number of embryos dying at mid-pregnancy tends to reduce litter size to 'normal'. This observation suggests that, whereas systemic factors may be responsible for the retardation of development seen shortly after implantation, the number of conceptuses which survive may be determined by local factors, such as the vascular supply to the uterus.

In conclusion, the present results suggest that factors in the maternal environment are at least partly responsible for the increased incidence of embryonic mortality in mice which have superovulated. Changes in the output of ovarian hormones, perhaps induced by the administration of PMSG and HCG, are liable to affect cleavage, tubal transport and the functional efficiency of the uterus after implantation. Direct measurement of the levels of circulating steroids will be required to substantiate the hypothesis that embryonic loss is related to hormonal change. Further investigations of the process of fertilization and early development are needed to show whether oocytes with chromosomal abnormalities contribute to the substantial losses which occur during the pre-implantation period.

\section{ACKNOWLEDGMENTS}

We wish to thank Professor J. T. Eayrs, Dr E. G. Jones, Dr L. L. Franchi and Mr T. Marshall for advice and helpful discussion. Financial support was received from The Population Council (Grant No. M71.168) and from the U.S. Atomic Energy Commission (Grant No. AT(11-1) 3114).

\section{REFERENCES}

ALLEN, J. \& MCLAREN, A. (1971) Cleavage rate of mouse eggs from induced and spontaneous ovulation. F. Reprod. Fert. 27, 137-140.

Austin, G.R. (1970) Ageing and reproduction: post-ovulatory deterioration of the egg. F. Reprod. Fert., Suppl. 12, 39-53.

Beck, F. \& Lloyd, J.B. (1966) The teratogenic effects of azo dyes. Adv. Teratol. 1, 131-193.

BerRY, G.L. (1970) The effect of trypan blue on the growth of the rat embryo in vivo. F. Embryol. exp. Morph. 23, 213-218.

Biggers, J.D., WhitTen, W.K. \& WhitTingham, D.G. (1971) The culture of mouse embryos in vitro. In Methods in Mammalian Embryology, Ch. 6, pp. 86-116. Ed. J. C. Daniel. Freeman, San Francisco.

DANIEL, J.C. (1964) Some effects of steroids on cleavage of rabbit eggs in vitro. Endocrinology 75, 706-710.

Dickson, A.D. (1966) The form of the mouse blastocyst. F. Anat. 100, 335-347.

EDWARDS, R.G. \& FowLER, R. (1959) Foetal mortality in adult mice after superovulation with gonadotrophins. F. exp. Zool. 41, 299-322.

EDWARDs, R.G. \& Gates, A.H. (1959) Timing of the stages of the maturation divisions, ovulation, fertilization and the first cleavage of eggs of adult mice treated with gonadotrophins. F. Endocr. 18, 292-304.

EDWARDs, R.G., Wirson, E.D. \& Fowler, R. (1963) Genetic and hormonal influences on ovulation and implantation in adult mice treated with gonadotrophins. F. Endocr. 26, 389-399.

FowLER, R.E. \& EDWARDS, R.G. (1957) Induction of superovulation and pregnancy in mature mice by gonadotrophins. F. Endocr. 15, 374-384.

Fujimoto, S., Pahlavan, N. \& Dukelow, W.R. (1974) Chromosome abnormalities in rabbit preimplantation blastocysts induced by superovulation. F. Reprod. Fert. 40, 177-181.

Gardner, R.L. (1971) Manipulations on the blastocyst. Adv. Biosci. 6, 279-301.

GARDNER, R.L. (1972) An investigation of inner cell mass and trophoblast tissues following their isolation from the mouse blastocyst. F. Embryol. exp. Morph. 28, 279-312.

Gates, A.H. (1956) Viability and developmental capacity of eggs from immature mice treated with gonadotrophins. Nature, Lond. 177, 754. 
Gates, A.H. (1965) Rate of ovular development as a factor in embryonic survival. In Preimplantation Stages of Pregnancy, pp. 270-288. Ciba Fndn Symp. Eds G. E. W. Wolstenholme \& M. O'Connor. Churchill, London.

Gates, A.H. (1971) Maximizing yield and developmental uniformity of eggs. In Methods in Mammalian Embryology, Ch. 4, pp. 64-75. Ed. J. C. Daniel. Freeman, San Francisco.

GreENwALD, G.S. (1967) Species differences in egg transport in response to exogenous estrogen. Anat. Rec. 157, 163-172.

Harrington, F.E. (1965) Transportation of ova and zygotes through the genital tract of immature mice treated with gonadotropins. Endocrinology 77, 635-640.

Jones, E.C. \& KROHN, P.L. (1961) The relationship between age, number of oocytes and fertility in virgin and multiparous mice. F. Endocr. 21, 469-495.

KiRkPatrick, J.F. (1971) Differential sensitivity of pre-implantation mouse embryos in vitro to oestradiol and progesterone. 7. Reprod. Fert. 27, 283-285.

Malaren, A. (1967) Regulation of ovulation rate after removal of one ovary in mice. Proc. R. Soc. B, 166, 316-340.

McLaren, A. \& Bowman, P. (1973) Genetic effects on the timing of early development in the mouse. 7. Embryol. exp. Morph. 30, 491-498.

MaLaren, A. \& Michie, D. (1956) Studies on the transfer of fertilized mouse eggs to uterine fostermothers. I. Factors affecting the implantation and survival of native and transferred eggs. 7. exp. Biol. 33, 394-416.

Malaren, A. \& Mickie, D. (1959) Superpregnancy in the mouse. I. Implantation and foetal mortality after induced superovulation in females of different ages. 7 . exp. Biol. 36, 281-300.

Psychoyos, A. (1967) The hormonal interplay controlling egg implantation in the rat. Adv. Reprod. Physiol. 2, 257-277.

Snell, J. \& Stevens, L. (1966) Early embryology. In Biology of the Laboratory Mouse, Ch. 12. pp. $205-245$. Ed. E. L. Green. McGraw-Hill, New York.

Theller, K. (1972) The House Mouse. Springer, Berlin.

WhitTEN, W.K. (1957) The effect of progesterone on the development of mouse eggs in vitro. F. Endocr. $16,80-85$. 